logos_i_ethos_2020_special issue, pp. 7-27

DOI: http://dx.doi.org/10.15633/lie.3765

Amadeusz Pala

ORCID:https://orcid.org/0000-0002-3622-6461

\title{
The structure of man-person dynamism in Karol Wojtyła's adequate anthropology
}

As a philosopher, Karol Wojtyła created adequate anthropology, which "attempts to understand and explain man in that which is essentially human." ${ }^{1}$ This kind of philosophical anthropology is distinguished by a broad research perspective whereby the image of

Amadeusz Pala - Ph. D., an Assistant Lecturer at the Faculty of Philosophy, the Pontifical University of John Paul II in Cracow (WF UPJPII). He is the author of the books: Dynamizm człowieka $w$ ujęciu filozoficznym Karola Wojtyly i Józefa Tischnera (Cracow, 2019), Śmierć na miarę człowieka (Cracow, 2014). man grounded on the Aristotelian-Thomistic tradition becomes enriched with phenomenological analysis. In other words, the thinker tries to combine the approach of object philosophy - philosophy of being with the approach of subject philosophy - philosophy of consciousness. This wide-ranging philosophical profile of Karol Wojtyła's is an area in which man is examined with regard to his special activity, that is conscious and free acts, which are an expression of his aspiration towards fulfilment as a person.

The foremost role in this philosophy is played by the issue of dynamism of man-person, of his becoming. ${ }^{2}$ Wojtyła emphasises it very strongly, for

1 Jan Paweł II, Mężczyzna i niewiastą stworzył ich. Chrystus odwołuje się do „początku," Lublin 1981, p. 51.

${ }^{2}$ However, the reception of this issue can be manifold. Having read The Acting Person, Józef Tischner said: "And there is one more sense of unfulfilled satisfaction [...]. Obviously, it is not about one more chapter, but about the problem of a person's becoming. In Scheler, Husserl, Heidegger, a "person» is that which he is becoming. In Thomism a person is" (J. Tischner, Metodologiczna strona dzieła „Osoba i czyn”, „Analecta Cracoviensia” 5-6 [1973-1974], p. 89). However, from the present paper one can learn that Wojtyła does not analyse a person's becoming, because he presupposes that 
instance by employing a special term (fieri) with the aid of which he tries to highlight this unique character of human dynamism. However, it must be admitted that understanding Wojtyła's concept poses quite a challenge - in order to outline a relatively transparent structure of this dynamism, one needs to appropriately associate specific passages in his texts. Thus, the aim of the present paper $^{3}$ is to bring out the most important elements that make up the structure of man-person dynamism as viewed within the framework of adequate anthropology. Accomplishing this requires an introduction to the Polish personalist's philosophy.

\section{On the concept of man-person}

Wojtyła had no doubts whatsoever as to the personal dimension of human being. In his introductory speech, during the discussion of The Acting Person at the Catholic University of Lublin, on 16 December 1970, he stated: "The reality of a person presses against us from all sides, which is evidenced not only by written sources, but above all by life, existence, man's standing in the world, development processes and their proper meaning." ${ }^{4}$ As can be clearly seen, he found the issue to be obvious,

a person as such is not subject to becoming (that is, he presupposes that man is always the same person - a person's identity is not subject to change). That which is subject to becoming is the person's selfhood (i.e. "personality" sensu largo), particularly in the moral dimension. This type of becoming is in detail investigated by Wojtyła thanks to the employment of the category of lived experience. If Wojtyła had adopted different presuppositions, closer to Tischner's views, then the analysis of becoming might apply to the person himself - this, however, would mean that Wojtyła's philosophy would be characterised by a completely different dimension. For this reason, the above remark of Tischner's seems misguided, because it does not apply to that which Wojtyła proposes, but to that which he might propose if only he changed his views.

3 The present paper is based on passages from my doctoral dissertation entitled The Dynamism of Man in Karol Wojtyła's and Józef Tischner's Philosophical Approach, and defended at the Faculty of Philosophy, the Pontifical University of John Paul II in Cracow, 16 May 2018.

${ }^{4}$ K. Wojtyła, Wypowiedź wstępna w czasie dyskusji nad „Osoba i czynem” w Katolickim Uniwersytecie Lubelskim dnia 16 grudnia 1970 r., „Analecta Cracoviensia” 5-6 (1973-1974), p. 54. "[...] irrespective of different worldviews, everyone in a way agrees with this statement. In a sense it determines a man's position in the world that is specific to him. It conveys his natural greatness. Man is superior to all nature, towers above everything that we encounter in the visible world" 
and so his intention was to engage in not so much substantiation, but rather explication, primarily within the framework of phenomenological analyses. However, it must be emphasised that the course of these analyses was in a way guided by some kind of "fundamental hypothesis," constituted by Aristotelian-Thomistic premises concerned with being that he adopted. ${ }^{6}$ That is why he viewed his philosophical method as proceeding "from a phenomenon to a foundation." 7 To be more precise, his phenomenological analyses appear to be somewhat dependent on the expected "confirmation" of the metaphysical presuppositions (which, however, does not necessarily have to mean that the presuppositions completely determined the course of these analyses). ${ }^{8}$ The Boethian definition of person is the key element in these presuppositions. ${ }^{9}$

(K. Wojtyła, Człowiek jest osoba, in: K. Wojtyła, „Osoba i czyn” oraz inne studia antropologiczne, Lublin 2000, p. 418).

5 This expression was used by Italian philosopher Rocco Buttiglione: “Therefore, the metaphysical Thomistic anthropology is here in a way present all the time, as a grand fundamental hypothesis which comes to be verified by a phenomenological analysis, and which - on the other hand - constantly guides the analysis, allowing it to become more profound" (R. Buttiglione, Kilka uwag o sposobie czytania „Osoby i czynu”, in: K. Wojtyła, „Osoba i czyn” oraz inne studia antropologiczne, op. cit., p. 15).

6 Also as John Paul II he continued to support this position: "One might, for instance, employ the phenomenological method to analyse experiences, such as the experience of morality, religion or humanity, thereby considerably enriching our cognition. However, one should not forget that all these analyses in a way tacitly presuppose the reality of human being" (Jan Paweł II, Pamięć i tożsamość. Rozmowy na przełomie tysiącleci, Kraków 2005, p. 21).

7 "We face a great challenge at the end of this millennium to move from phenomenon to foundation, a step as necessary as it is urgent. We cannot stop short at experience alone; even if experience does reveal the human being's interiority and spirituality, speculative thinking must penetrate to the spiritual core and the ground from which it rises" (John Paul II, Encyclical Fides et ratio, no. 83).

8 The issue of this relationship may appear not to be perfectly clear. However, it is a separate issue that goes beyond the subject of this paper. In any case, it proves that Wojtyła cannot be regarded as an out-and-out phenomenologist, because a phenomenologist should not presuppose a substantial nature of an object that appears in experience. He was of the opinion that research that stops short at analysis of experiences alone cannot be regarded as investigation of entire reality. Hence, he found some kind of hermeneutics to be complementary to the phenomenological method: in The Acting Person, having described the act, he goes on to interpret it.

9 "The person would be an individual whose nature is rational - according to Boethius' full definition persona est rationalis naturae individua substantia" (K. Wojtyła, The Acting Person, trans. Andrzej Potocki, Dordrecht: Holland 1979, p. 73). 
However, in Wojtyła's opinion this classical and realist concept of person does not exhaust the entire wealth of the truth about man. ${ }^{10}$ Likewise, he did not find the category of metaphysical suppositum alone as the subject of existence and action, which he often mentioned (considering it to be particularly valuable), to be sufficient interpretation of the entirety of human reality. In his opinion, such definitions or notions show manperson rather from the objective aspect, and do not reveal too much about his subjective aspect. His intention was to show not only "what man is," but chiefly "how man experiences himself." Hence, he writes about his major philosophical work the following: "Many of the analyses performed in The Acting Person are closely related to the problem of subjectivity of the human person; one might even go as far as to say that all of them serve to enable its understanding and exposition." ${ }^{11} \mathrm{He}$ confirms this belief of his in many other places, e.g. the paper Podmiotowość $i$ "to, co nieredukowalne" $w$ człowieku, where he writes as follows: "we feel a need, which is stronger than ever before, [...] to objectivise the problem of the subjectivity of man." ${ }^{12}$

In order to show the specificity of the subjectivity of man, Wojtyła uses a category of "lived experience," which is not to be found in Aristotle's metaphysics. To investigate 'a lived experience' he employs the above-mentioned method of phenomenological analysis, which he treats not only as a description registering individual phenomena, but also as investigation enabling cognitive penetration of the entire essence of a lived experience. Thus, the philosopher examines not only the structure of lived experience itself (which is essentially subjective), but also its structural relation to the subjectivity of man. More specifically, the course of the whole analysis is as follows: we start out with a description

10 Wojtyła is explicit on this definition, writing that "it expressed the individuality of man as a substantial being endowed with rational nature, [...] rather than the entire specificity of subjectivity essential for man as a person” (K. Wojtyła, Podmiotowość i „to, co nieredukowalne” $w$ człowieku, in: K. Wojtyła, „Osoba i czyn” oraz inne studia antropologiczne, op. cit., p. 438).

11 K. Wojtyła, Osoba: podmiot $i$ wspólnota, in: K. Wojtyła, „Osoba i czyn” oraz inne studia antropologiczne, op. cit., p. 373.

12 K. Wojtyła, Podmiotowość i „to, co nieredukowalne” w człowieku, op. cit., p. 435. 
of phenomena (sense content) and the attendant experiences, proceed through transphenomenal understanding and reach the one and unique subjectivity of man-person. ${ }^{13}$ Importantly, the interpretation performed thanks to the category of lived experience does not constitute a step towards subjectivism. It is more about showing human subjectivity, but always with regard for the realist concept of being. This also involves a more accurate exposition of internal experience, which does not, however, mean its absolutisation as opposed to external experience, because both the types of experience constitute equivalent aspects of man's experience as a whole. ${ }^{14}$ With the benefit of this interpretation, Wojtyła presents man-person not only as an existing and acting subject, but also as a subject experiencing himself as existing and acting one, that is as a subject experiencing his subjectivity itself. ${ }^{15}$

With such analyses the thinker was able to advance a fundamental proposition whereby apart from "that which is reducible" to metaphysical categories (e.g. suppositum - the subject of existence and action), manperson contains "that which is irreducible" to these categories (e.g. experiencing one's own subjectivity). In other words, disregarding the subject's capability for experiencing himself would be tantamount to treating him only in objective terms, that is only as an object reducible to metaphysical categories, whereas experience serves as incontrovertible evidence that the subject "eludes" such reduction. ${ }^{16}$ Still, the claim that Wojtyła absolutises or values "that which is irreducible" in man more

13 Cf. K. Wojtyła, Podmiotowość $i$ „to, co nieredukowalne” w człowieku, op. cit., p. 442

$14 \mathrm{~K}$. Wojtyła believes man's experience "must give rise to the conviction whereby any absolutisation of either of the two aspects of man's experience must yield when faced with the need for their mutual relativisation" (K. Wojtyła, Osoba i czyn, op. cit., p. 67).

15 In this context Wojtyła writes: "the point is to show the person as a subject having a lived experience of [...] his subjectivity” (K. Wojtyła, Podmiotowość $i$,to, co nieredukowalne” w człowieku, op. cit., p. 439).

16 "In its essence, a lived experience is based on reduction, which does not, however, mean that it breaks free from our cognition. It only demands that cognition of it is acquired differently, that is with the aid of such a method, and pursuing such an analysis that only reveals and manifests its essence. The method of phenomenological analysis allows us to dwell on the lived experience" (K. Wojtyła, Podmiotowość i „to, co nieredukowalne” w człowieku, op. cit., p. 442). 
highly is untenable. His intention was only to cognitively dwell on the issue, giving it more attention. What is more, he even warned against such absolutisation, stating that one should not "remain within the sphere of just «that which is irreducible» (which would mean incapacity to go beyond pure «I»)."17 Thus, he was anxious to strike some balance between "that which is reducible" and "that which is irreducible" although he was convinced that the balance is possible only when we acknowledge that the latter is ontologically conditional upon the former, and not vice versa. ${ }^{18}$ By way of illustration, the thing is that man is always a person (hence the expression: "man-person"), that is already at the level of his metaphysical suppositum (existing as a person), even though this truth about his all-important subjectivity can be discovered by him only at the level of lived experience (available to persons only). Otherwise, it would be erroneous to consider that conscious lived experience of one's subjectivity conditions the personal status - which at the same time means opposition to all manner of consciousness-based concepts of person. ${ }^{19}$ It is worth noting that the concept of consciousness ${ }^{20}$ offered by adequate anthropology is quite complex (and is a crucial

17 K. Wojtyła, Podmiotowość $i$,to, co nieredukowalne” w człowieku, op. cit., p. 440.

18 Even though in his research Wojtyła focused on man as the subject, he was also an adherent to objectivism and realism. Since he was aware of possible vagueness resulting from this, he would sometimes expound on this issue. For instance, at the beginning of Love and Responsibility he writes that "if we begin with a 'subject' [...] it is easy to treat everything which is outside the subject, i.e. the whole world of objects, in a purely subjective way [...]. We must, then, be clear right from the start that every subject also exists as an object" (K. Wojtyła, Love and Responsibility, trans. H. T. Willetts, San Francisco 1981, p. 21).

19 "Any analysis of the human being [...] if it were to be grounded on consciousness alone, would from the first be doomed to inadequacy" (K. Wojtyła, The Acting Person, op. cit., p. 91).

20 Wojtyła's concept of consciousness might be summed up thus: first and foremost, consciousness does not constitute an absolute cognitive subject, but is merely an aspect of human being. What is more, it does not even have a cognitive function and, by extension, it does not provide any knowledge or self-knowledge (knowledge about the subject). Nevertheless, it plays a crucial role, because it accompanies cognition, performing mirroring and reflective functions. The mirroring function consists in the contents already recognised by reason becoming objectified (mirrored, or scanned by consciousness), thus becoming in a way obvious for the subject. Then, thanks to the reflective function the contents become subjectified (interiorised, or internalised) by the person, thus becoming the contents of his personal lived experiences. Cf. K. Wojtyła, The Acting Person, op. cit., pp. 25-45. 
element in Wojtyła's exposition), and so its presentation would require a separate paper. Therefore, the scope of the present paper only allows for a statement whereby consciousness does not determine being a person, but only experiencing the fact that one already is a person (or more appropriately, it determines the constitution of "I" in the sense of lived experience). ${ }^{21}$

Wojtyła's aspiration was for the understanding of man in the world (of the cosmological type) to be complemented by the conception of man in himself (of the personalist type). ${ }^{22} \mathrm{He}$ believed that such complementation determines the meeting point for object and subject philosophies, and the point is man himself, in whom the demarcation line between the two approaches breaks - because man is both a subject and an object. ${ }^{23}$ This fundamental concept of his is to some extent connected with all other theories which he espoused. For instance, the theory of man-person's dignity, because it is only in a factual lived experience of one's own subjectivity that a person can find "corroboration" of the extraordinary perfection of his being (and not just theoretical deliberations about this perfection).

In large measure the purpose of the deliberations thus conducted was to show a correlation between a person and his act, because "the person and his action - as Wojtyła writes - are two poles; each strictly corresponds to the other; each displays and explains the other from its point of view." ${ }^{24}$ More precisely, in the work The Acting Person the philosopher's deliberation leads him to present a study of a person's action, whereby "action reveals the person, and we look at the person through his action." ${ }^{25}$ It is tentatively noteworthy that among all the

21 Cf. K. Wojtyła, The Acting Person, op. cit., pp. 45-47.

22 The experience of the human being cannot be derived by way of "cosmological» reduction; we must pause at «the irreducible», at that which is unique and unrepeatable in each human being, by virtue of which he or she is not «just a particular» human being - an individual of a certain species-but a personal subject" (K. Wojtyła, Podmiotowość i „to, co nieredukowalne” w człowieku, op. cit., p. 440).

23 Cf. K. Wojtyła, Podmiotowość i „to, co nieredukowalne” w człowieku, op. cit., p. 436.

24 K. Wojtyła, The Acting Person, op. cit., p. 261.

25 K. Wojtyła, The Acting Person, op. cit., p. 11. 
dynamisations of man-person, the dynamism of act has a very special place. Its better understanding will, however, require outlining the entire structure of those dynamic approaches, which can be encountered in the Polish personalist's philosophical writings.

\section{The structure of man-person dynamism}

It is to be posited that the structure of man-person dynamism contains two main levels: primary and secondary. Within the framework of these two levels three kinds of dynamism can be distinguished: dynamism of suppositum and dynamism of activations, both of which are to be found at the primary level, ${ }^{26}$ as well as dynamism of act, which is to be found at the secondary level.

The level of primary dynamism is in principle determined by the metaphysical suppositum as a subject of existence and action. The rational and free human nature is an important element of this level. ${ }^{27}$ In this sense: "nature - writes Wojtyła - provides the basis for the essential cohesion of the subject of dynamism with all the dynamism of the subject." 28 Therefore, suppositum as the subject of all dynamism possesses indispensable ontic conditions, a unique mode of existence (esse) necessary above all for the fully personal action (operari) to emerge,

${ }^{26}$ To be more precise, the dynamism of suppositum is more fundamental (constitutive) than the dynamism of activations. The proposed approach serves to convey the truth about the corporeal-spiritual unity of man-person, as well as to emphasise the difference between the dynamism of act and the other dynamisms.

27 It is about nature in the classical sense: "In the metaphysical approach nature is identical with essence, and thus nature in man is the same as the whole of his humanness, though humanness that is dynamic rather than static - because conceived as the basis of all the dynamism proper to man [...] Nature in the metaphysical sense is equivalent to the essence of any being, where essence is regarded as the basis for the dynamism of this being" (K. Wojtyła, The Acting Person, op. cit., p. 82). It is also worth adding that Wojtyła uses the term "nature" usually in two senses: metaphysical (denoting the essence of being) and phenomenological (denoting the source of activations). Besides, he makes a mention of the meaning of "nature" as "the material world," but he hardly ever uses it. Cf. K. Wojtyła, The Acting Person, op. cit., p. 76).

28 K. Wojtyła, The Acting Person, op. cit., p. 83. 
on the principle of operari sequitur esse. ${ }^{29}$ Therefore, already at this level man is a person equipped with all person-specific potentiality, thanks to which over the course of time he will be developing his personality (unless some congenital defects or external factors interfere). What is more, through the mere act of coming into existence, or even more so through some specific perfection of his being, such a man-person constitutes extraordinary good, ${ }^{30}$ which also serves as the basis for his personal dignity, ${ }^{31}$ which Wojtyła's personalist norm refers to. ${ }^{32}$

29 "The discovery of human suppositum, that is the subjectivity of man in the metaphysical sense, contains the basic approach to the relationship between existence and action. This relationship expresses the philosophical adagium "operari sequitur esse»" (K. Wojtyła, Osoba: podmiot i wspólno$t a$, op. cit., p. 378). This principle can be explained as follows: action is a consequence (or a manifestation) of existence. It is also worth noting that according to Wojtyła, this principle does not only express the causal dependence of action on existence, but also a gnoseological relationship: investigating operari enables cognition of esse, which is its cause. Cf. K. Wojtyła, Osoba: podmiot i wspólnota, op. cit., p. 379.

30 Wojtyła lays special emphasis on the Thomistic, existential concept of good. "This concept he writes - can be referred to as existential on account of the fact that Saint Thomas discerns a fundamental element of good in actual existence. It is the actual existence of specific perfection, that is of the one that corresponds to nature, that determines good. [...] The fuller the existence is, the fuller the being is, and by extension the greater good it is" (K. Wojtyła, Dobro i wartość, in: Wykłady lubelskie, Lublin 2006, p. 142).

31 For Wojtyła, treating man-person as being-good, or as a being endowed with a rational nature is, in other words, tantamount to understanding him in a cosmological manner, which does not sufficiently reveal the personalist profile. That is why in his discussion he paid more attention to the issue of personal dignity. In other words, he wanted to treat man not only as a being among other beings, as a nature among other natures, but as a person with a special position in this world, with a certain distinctness and primacy. Cf. K. Wojtyła, Człowiek w polu odpowiedzialności, RzymLublin 1991, p. 85.

32 Wojtyła develops his moral norm by reformulating and enriching the Kantian imperative. It reads as follows: "whenever a person is the object of your acting, remember that you must not treat that person as only the means to an end, as an instrument, but must allow for the fact that he or she, too, has, or at least, should have, distinct personal ends" (K. Wojtyła, Love and Responsibility, op. cit., p. 28). Interestingly enough, he precedes it with some emphatic statement, namely: "Nobody can use a person as a means towards an end, no human being, nor yet God the Creator. On the part of God, indeed, it is totally out of the question, since, by giving man an intelligent and free nature, he has thereby ordained that each man alone will decide for himself the ends of his acivity..." (K. Wojtyła, Love and Responsibility, op. cit., p. 27). 
The dynamism of activations is about "things happening in a human being" (actus hominis) irrespective of his will or consciousness. It is about somatic-vegetative and psycho-emotive processes. To some degree the subject is capable of observing what is happening in him (which can be instantiated by the development of biology or medicine), but this fact does not directly give rise to considerable change in activations (of course, it is possible to exert indirect influence on the organism, e.g. by choosing conditions for its development or deciding about the course of treatment). Wojtyła calls this dynamism passive (pati), because it is determined by a whole lot of physiological functions of the body (one of them is sexual urge, which he analyses while discussing the subject of love). It must also be clearly stressed that the dynamism of activations has been reckoned as belonging at the primary level not because it is as equally constitutive as the dynamism of suppositum (for in fact it is conditioned by it), but because man is a peculiar corporeal and spiritual unity, within the framework of which the category of biological life can be recognised as a certain "face" of his existence. On account of the fact that this "face" of the dynamism of activations, which makes up the entirety of man's life functions, is observable, it falls within the compass of phenomenological investigation, unlike the ontic dynamism, which is subject to metaphysical considerations.

On the other hand, the dynamism of act occurs only when "man acts" (actus humanus) with complete consciousness and freedom. And so, unlike the previous, passive dynamism, it is characterised by an active (agere) ${ }^{33}$ dimension. A key role is played here by the capability for conscious experiencing of this dynamism, because it enables emergence of the structure of personal self-determination, which includes self-control and self-possession. ${ }^{34}$ Crucially enough, an experience of act is always accompanied by an experience of morality, thanks to which a person performing an act that realises a specific value himself becomes morally 
good or bad. ${ }^{35}$ Therefore, this dynamism is about a person's fulfilment through an act (actus personae). Wojtyła needed the phenomenological method in large measure to investigate this dynamism. He found the method helpful in showing, among others, that every conscious action is accompanied by consciousness of this conscious action, ${ }^{36}$ which makes it possible to discover one's personal efficacy and responsibility for the act. Wojtyła writes: “There is between person and action a sensibly experiential, causal relation, which brings the person, that is to say, every concrete human ego, to recognize his action to be the result of his efficacy." ${ }^{37}$ It is also noteworthy that man's efficacy, so strongly emphasised by Wojtyła, was in opposition to the stance adopted by Max Scheler, who - in Wojtyła's opinion - ultimately rejected it in favour of emotionalist yielding to values. ${ }^{38}$

It must be stressed that the thing that separates the dynamism of activations from the dynamism of act - which in considerable measure

35 "Moral values - good and evil - not only determined the inner quality of human actions, but they also never enter into a dynamic sequence of actions without leaving an imprint whereby man as a person, owing to his actions that may be good or may be evil, himself becomes either good or evil” (K. Wojtyła, The Acting Person, op. cit., p. 12-13).

36 "Man has the self-knowledge of his being conscious and because of it he is aware of the consciousness of his being and acting" (K. Wojtyła, The Acting Person, op. cit., p. 37).

37 K. Wojtyła, The Acting Person, op. cit., pp. 67.

38 Wojtyła performs an in-depth analysis of the issue of a person's efficacy in Max Scheler's ethics, becoming convinced that eventually this philosopher rejected it. A passage in Wojtyła's habilitation dissertation reads that "in the emotionalist structure of the system this denial results from a radical separation of a person's efficacy from his love. In consequence, a person lives emotion and cognition, but is not an agent of values which become realised in his willingness. [...] as a result of the emotionalist presuppositions underlying the entirety of Scheler's system, moral values cannot be an object of a person's efficacious act. Scheler was so radical and exclusive about combining them with a person's emotional sphere of life, while the sphere being thoroughly separated from the causative energies of the will, that the person in fact cannot be their efficient cause" (K. Wojtyła, Ocena możliwości zbudowania etyki chrześcijańskiej przy założeniach systemu Maxa Schelera, op. cit., pp. 75-76). However, Wojtyła knows that this conclusion did not arise straight away, because: "in Scheler's concept «willingness» has a paradoxical sense: a person sets himself goals and at the same time yields to the values that the goals constitute. While on the first account we have a right to see willingness as a true manifestation of a person's efficacy, on the second account we must give it up. And the second account is in keeping with the presuppositions of the entire system" (K. Wojtyła, Ocena możliwości zbudowania etyki chrześcijańskiej przy założeniach systemu Maxa Schelera, op. cit., p. 75). 
is the operation of the efficacy - does not give rise to their mutual exclusion. On the contrary, there is some unilateral relationship at play here, namely: without that "which is happening in a human being," "man's action" would be impossible (but it is possible to have activations without any acts). More specifically, the dynamism of activations conditions the dynamism of act in that various moments of activations, which are responsible for proper workings of the organism, are used by dynamism of act as some kind of raw material (e.g. the above-mentioned sex drive)..$^{39}$

It is also to be noted that every conscious action requires that man be entirely involved, that is all the three, above-described types of dynamism are brought to bear. The dynamism of act is viewed as secondary to the two basic ones, because: (1) the primary ones make it possible, (2) it is not necessary for them to emerge, (3) and hence its emergence does not take place at the same time as the other two (it does not occur above all in the first stages of the subject's existence-life), (4) its appearance automatically involves the other two. Therefore, despite the fact that there are various ways of dynamising man-person, it is impossible to find his cohesion or identity to be lacking ${ }^{40}$. This is chiefly because the secondary dynamism has its origins in the primary dynamism. In this context Wojtyła writes: "In the man-subject [dynamic unity] consists [...] primarily in the unity of life and only secondarily and, as it were, accidentally in the unity of experience." ${ }^{\prime 1}$

39 "The sexual urge does not itself produce complete, finished actions, it only furnishes, so to speak, in the form of all that «happens» in man's inner being under its influence, what might be called the stuff from which action is made" (K. Wojtyła, Love and Responsibility, op. cit., pp. 49-50).

40 "When man acts, the ego has the experience of its own efficacy in action. When, on the other hand, there is something happening in man, then the ego does not experience its own efficacy and is not the actor, but it does have the experience of the inner identity of itself with what is happening and, at the same time, of the exclusive dependence of what is happening upon itself. What takes place in myself in the form of various activations is the property of my ego and, what is more, it issues from my ego, which is its only appropriate substratum and cause, though then I have no experience of my causality, of my efficacious participation, as I have in actions" (K. Wojtyła, The Acting Person, op. cit., p. 80).

41 K. Wojtyła, The Acting Person, op. cit., p. 91. 
The following passage from The Acting Person aptly summarises the above-mentioned issues: "Once we reach the insight into the man-person as the ontological basis for existence, we can see in him a synthesis of [...] dynamic structures [...]. The two structures, that in which man acts and that in which something happens in man, cut across the phenomenological field of experience, but they join and unite together in the metaphysical field. Their synthesis is the man-person, and we discover the ultimate subject of the synthesis in its ontological groundwork. Not only does this groundwork [suppositum] underlie the whole dynamism of the manperson, but it itself is also the dynamic source of the dynamism. The dynamism derived from the actual existence [esse] has as its consequence the dynamism pertaining to activity [operari] ${ }^{342}$ Further on, the reader finds the following: "It is in man, the personal «somebody», that the activations that happen in him have their origin just as much as it is from him that spring the actions he as the actor performs." ${ }^{\text {"3 }}$ When all is said and done, all the dynamisms fuse together into one dynamism of suppositum (which always features the human "I"), which ensures a synthesis of the dynamic entirety, that is man-person. A separate presentation of these three dynamisms only made for their better understanding, and not actual separation. Such was the research method employed by Wojtyła himself, mainly whenever he - while analysing consciousness - would "keep it out of the equation," which helped him better emphasise both that which was out of the equation (consciousness) and that which remained in it (suppositum). ${ }^{44}$ Likewise here, as a result of this methodical device: principally the dynamism of act, but also to some degree the dynamism of activations have been "removed from the equation," within which remains the dynamism of suppositum as the most original one. It is noteworthy that the method employed is not about the same as the Husserlian method of "bracketing," because unlike it, it does not require withholding the judgment about the real existence of things.

42 K. Wojtyła, The Acting Person, op. cit., pp. 74-75.

43 K. Wojtyła, The Acting Person, op. cit., p. 80.

44 Cf. K. Wojtyła, The Acting Person, op. cit., p. 30. 
A crucial question concerned with the subject of dynamism and the unity of subject is connected with the "integration of nature in the person." ${ }^{35}$ To understand it right, one needs to know that in this context Wojtyła uses the terms of "nature" and "person" in their special meanings ${ }^{46}$ - phenomenological and not metaphysical ones. Thus, in the phenomenological interpretation these concepts denote only certain modes (modus) in which the subject gets dynamised. In this sense: nature becomes revealed in the dynamism of activations, and the person - in the dynamism of act. ${ }^{47}$ This interpretation also brings an important issue concerned with two varieties of causality: "causality of nature" (passive) and "causality of the person" (active). It should be noted that thus this phenomenological field provides grounds for opposing the person to nature in man, which on the one hand enables better depiction of man's dynamism, but on the other hand demonstrating the inadequacy of such semantic reduction from the metaphysical perspective, ${ }^{48}$ because in reality both the modes of dynamisation are closely integrated within one suppositum.

\section{Fieri as an aspect of human dynamism}

Dynamism involves fulfilment of various potentialities, ${ }^{49}$ which suppositum is equipped with - and of which the subject continually

45 Cf. K. Wojtyła, The Acting Person, op. cit., p. 80.

46 A phenomenological interpretation of the concepts of "nature" and "person" may give rise to misunderstandings. It was criticised by Jerzy Kalinowski, who believes that such an opposition of 'nature' and 'person' may "create a wrong impression whereby in this section of the personalist concept of man Saint Thomas was wrong” (J. Kalinowski, Metafizyka i fenomenologia osoby ludz$k i e j$, „Analecta Cracoviensia” 5-6 [1973-1974], pp. 70-71). More details on this issue can be found in M. Czachorowski, Osoba a natura. Ujęcie Karola Wojtyły, in: Wokół antropologii Karola Wojtyły, Lublin 2016, pp. 307-352.

47 Cf. K. Wojtyła, The Acting Person, op. cit., p. 78-79.

48 Such detached modes of man-person dynamisation do not function in reality, and so in fact " $\mathrm{t}]$ here is, therefore, no valid reason for the mutual opposition in man of person and nature; on the contrary, we now see the need of their integration" (K. Wojtyła, The Acting Person, op. cit., p. 79).

49 These potentialities differ with regard to their functions or belonging at a given level of dynamism: (a) somatic-vegetative, (b) psycho-emotive, (c) cognitive, (d) of a personal subject 
experiences consequences, becoming more and more "of a specific kind," or more and more "someone." Thus, on the one hand, he is an initiator of changes taking place within him, and on the other hand - the purpose of these changes, because in a sense change "touches" the subject, leaving in him some trace (and so because of this we can speak about man's actual becoming).$^{50}$ Of course, dynamism is already at play at the stage of suppositum causality (including causality of nature and of the person), but it does not stop right there; the dynamism effects some kind of "grounding" of a given effect in the subject (the effect produced exactly as a result of the causality). ${ }^{51}$ Wojtyła emphasises this special meaning of the reflexive (self-directed) aiming of dynamism at the subject by employing the concept of fieri. "By «becoming» [fieri] we mean such an aspect of the human dynamism [...] that does [...] center on man himself, the subject of this dynamism." ${ }^{52}$ Negatively speaking, without fieri any possible "dynamism" would be pointless, and would not realise any capability - which in turn would give rise to contradiction, because dynamism must essentially bring some novum. Therefore, this necessary aiming of dynamism at the subject constitutes an auto-teleological dimension of human dynamism. It is also worth noting that in this sense this peculiar movement - dynamism - does not only "arise" from man (by way of causation), but it also "returns" to him (which is manifested by fieri). Thus, the subject is both the cause and effect of his own dynamism. For him, being an effect means being an effect of the changes happening

(self-consciousness), (e) of will. See K. Wojtyła „Osoba i czyn” oraz inne studia antropologiczne, op. cit., pp. 84, 86, 137, 145, 146, 412, 449, 482.

50 The subjectivity of a person can be considered as an ontological subjectivity, which is given to every man, and as a functional subjectivity, which is presented to every man as a task. The former one can also be regarded as an initial subjectivity, while the latter one - as a final subjectivity, an effect of many years' personal development. Cf. M. Sztaba, Człowiek jako byt moralny w myśli Karola Wojtyly - Jana Pawła II, in: Człowiek w refleksji Karola Wojtyły - Jana Pawła II. Wybrane aspekty adekwatnej antropologii, ed. A. Różyło, M. Sztaba, Lublin 2014, p. 121.

51 " [...] [I]n all dynamizations the subject does not remain indifferent: not only does it participate in them [...] but it is itself in one way or another formed or transformed by them" (K. Wojtyła, The Acting Person, op. cit., p. 96).

52 K. Wojtyła, The Acting Person, op. cit., p. 96. 
in him or the ones that he himself triggers by acts. To put it straight: he is the kind of man that he is changing into. It must be emphasised that the dynamism does not affect his identity, but only his selfhood: for he is still the same man-person, even though over the course of time his self is no longer the same (the only change taking place in him is the one with regard to quality and not essence).

Importantly, every kind of dynamism is characterised by its specific fieri. The most important fieri of man-person is his esse, which belongs to the dynamism of suppositum. Wojtyła writes: "The initial, original dynamization of the individual being as such is simultaneously the first instance of becoming of the human being." ${ }^{3}$ And so suppositum is dynamic not only because it contains potentiality for change and development, but also on account of its very emergence and continuity, ${ }^{54}$ that is the overall course of its existence, which can be captured with the expression esse-fieri. As we move on, it is to be concluded that esse-fieri provides foundation for internal differentiation of fieri within the subsequent kinds of dynamism.

The first kind is fieri in the somatic-vegetative sphere (Wojtyła terms it in fieri). ${ }^{55}$ The second one is fieri in the psycho-emotive sphere. Both these spheres belong to the dynamism of activations, and so are passive, furnishing mainly conditions for development (even though the psychoemotive sphere is characterised by additional malleability). ${ }^{56}$ Depending on their specific spheres, these two kinds of fieri are responsible for establishing in the subject the consequences that arise as a result of "causality of nature" (owing to this the organism sustains itself, reconstructs itself and develops). ${ }^{57}$

53 K. Wojtyła, The Acting Person, op. cit., p. 96.

54 It is his parents and God that are responsible for man-person's coming into existence.

55 Cf. K. Wojtyła, The Acting Person, op. cit., p. 97.

56 "The human organism - as the philosopher writes - determines almost entirely its own development, and only the conditions of the development are established by man. The situation is the opposite in the psychoemotive sphere, which itself establishes the conditions and, as it were, supplies the material for its own development; consequently, the formation of this sphere mainly depends on the human person" (K. Wojtyła, The Acting Person, op. cit., p. 98).

57 Cf. K. Wojtyła, The Acting Person, op. cit., pp. 97-98. 
Last but not least, fieri in the conscious-volitive sphere, specific to the dynamism of act. ${ }^{58}$ This kind of fieri conditions the establishment in the subject of the moral effect produced by an act effected by "causality of the person." Of course, an act produces effects of different kinds as well, but an act always involves a moral effect (an experience of an act always goes hand in hand with an experience of morality). For instance, physical activity undertaken with a view to improving one's health does not only produce the effect of greater fitness, but also realises some moral good with regard to properly construed self-love. Thanks to such efficacy, man-person can practise self-determination - he can change something about his life, thereby becoming morally good or evil. "This becoming, or man's fieri which in moral terms - as Wojtyła writes - is most closely linked with the person, determines the realistic character of good or evil itself [...]. By no means are they contents of consciousness itself; they are contents of the human, personal fieri. Not only does man have a lived experience of them, but thanks to them he becomes really good or really evil." ${ }^{59}$ Wojtyła notes that "the concept of self-determination is more capacious than the concept of efficacy: man is not only an agent of his acts, but through these acts he is also in a way «a creator of himself». Action involves becoming - what is more, they are organically combined." ${ }^{\prime 0}$ Saying that man is more than just an agent of an act is another way of saying that his dynamism is something more than just causality - it is moulding oneself thanks to causality. However, man-person does not create himself in the absolute sense, but is only "becoming more and

58 "Man's act-related reflective turn to himself has its own conscious «background» in the form a special, fragmentary limit of this act, which guarantees the integrity of the subject of lived experiences and the act itself, and which is realised in statu fieri - the horizon of the «I». On the other hand, the horizon of being, which accompanies this turn to oneself, results in the grounding of the entire cognitive situation in the real reality" (W. Chudy, Rozwó j filozofowania a „pułapka refleksji”. Filozofia refleksji i próby jej przezwyciężenia, Lublin 1993, p. 86n). "Various forms of human activity cause continual enrichment of his personality, because man is incessantly «in statu fieri»" (M. Sztaba, Człowiek jako byt moralny w myśli Karola Wojtyły - Jana Pawła II, op. cit., p. 121).

59 K. Wojtyła, Osoba i czyn, op. cit., p. 204.

${ }^{60} \mathrm{~K}$. Wojtyła, Osobowa struktura samostanowienia, in: K. Wojtyła, „Osoba i czyn” oraz inne studia antropologiczne, op. cit., p. 427n. 
more «someone» in the personal-ethical sense, while in the ontic sense he has been "someone» from the very beginning." 61 Therefore, it is moderate dynamism of self-formation that is at play here at best, rather than some radical dynamism of creating oneself anew. ${ }^{62}$ Immutable ontic conditions contained in suppositum, that is a set of specific potentialities, are the things that do not allow such absolute creation. That is why man is not capable of transforming himself into something that he is not, and he can only form himself on the basis of what he already is - and hence the "structure of the human act is auto-teleological in a special dimension." ${ }^{63}$

Within Karol Wojtyła's adequate anthropology the dynamism of act is the highest form of man-person dynamisation. The other kinds of dynamism in a sense serve only as the basis for the emergence of action characteristic of personal being. In other words, it is not so much

${ }^{61}$ K. Wojtyła, Osobowa struktura samostanowienia, op. cit., p. 428.

62 "A deed, that is a personal act, action undertaken by a subject capable of objectification of itself, is part of the person-formative process. This does not mean that the person is not a person before performing a deed. The person serves as the basis for a deed, but every subsequent deed, as it expresses the person, grounds him in his own subjectivity. The purpose of a deed is a person's fulfilment, moving from a potency to an act. A deed is an act of personal self-fulfilment. Fulfilment is about quality enhancement. Karol Wojtyła excludes the first moment of becoming from the process of a person's self-fulfilment. Coming into existence is an act, but not a deed. A human being who acts, performs deeds on the basis of his existence. Because of deeds, a human being, who is a person already at the moment of coming into existence, becomes a person more and more fully" (W. Chudy, Rozwój filozofowania a "pułapka refleksji”. Dar według studium „Osoba i czyn” Karola Wojtyły, „Filozofia Dialogu” 1 [2003], p. 169).

${ }^{63}$ K. Wojtyła, Osoba: podmiot $i$ wspólnota, op. cit., p. 385. Being a goal of one’s own action does not, however, mean being confined to the structure of one's own dynamism. As the subject fulfils himself, he realises objective values by referring to all manner of external objects, which are frequently subjects like him, that is to other persons as ends in themselves. Such self-fulfilment of man-person is essentially about the affirmation of his dignity. This affirmation is directly or indirectly enabled by any deed, provided it is morally good. In his ethical study entitled Love and Responsibility, Wojtyła devotes a lot of space to show that a human being finds the most perfect self-fulfilment in interpersonal love, which is the opposite of "using" one's own and another person in terms of means to an end only. 
activations, or even preservation of his own existence, that is the most appropriate calling of man-person, but the act - after all it is only the act that enables full discovery of the meaning of human life. The philosopher also shows that the aspect of fieri has a particular meaning in the structure of human dynamism, because it is thanks to it that dynamism means real change - however, it is not a change of the subject (in the ontic sense), but a change in the subject (mainly in the moral dimension).

\section{Abstract \\ Structure of Man-Person Dynamism in the Adequate Anthropology of Karol Wojtyła}

The issue of dynamism plays an important role in Karol Wojtyła's philosophical anthropology. His study takes into account the context of the philosophy of being and the philosophy of consciousness. He emphasizes the importance of experiencing one's own subjectivity in the course of dynamism. The purpose of the article is to present the structure of human dynamism proposed by Wojtyła. It contains three types of dynamism: dynamism of suppositum, dynamism in a human being (when something happens to him) and dynamism of human action. The first is in the metaphysical field, two more in the phenomenological field. This structure also contains the fieri factor understood as directing the dynamism to the subject.

\section{Keywords}

Karol Wojtyła, dynamism, person, suppositum, fieri

\section{Bibliography}

Buttiglione R., Kilka uwag o sposobie czytania „Osoby i czynu”, in: „Osoba i czyn” oraz inne studia antropologiczne, ed. T. Styczeń, W. Chudy, J. W. Gałkowski, A. Rodziński, A. Szostek, Lublin 2000, pp. 9-42.

Chudy W., Rozwój filozofowania a „pułapka refleksji”. Filozofia refleksji i próby jej przezwyciężenia, Lublin 1993. 
Czachorowski M., Osoba a natura. Ujęcie Karola Wojtyły, in: Wokół antropologii Karola Wojtyly, ed. A. Maryniarczyk, P. Sulenta, T. Duma, Lublin 2016, pp. 307-352 (Zadania Współczesnej Metafizyki, 18).

Jan Paweł II, Encyclical Letter Fides et ratio, Rzym 1998.

Jan Paweł II, Mężczyznq i niewiasta stworzył ich. Chrystus odwołuje się do „początku”, Lublin 1981.

Jan Paweł II, Pamięć i tożsamość. Rozmowy na przełomie tysiącleci, Kraków 2005.

Kalinowski J., Metafizyka i fenomenologia osoby ludzkiej, „Analecta Cracoviensia” 5-6 (1973-1974), pp. 63-71.

Parzych K., Na progu teologii dialogu. Dar według studium „Osoba i czyn” Karola Wojtyły, „Filozofia Dialogu” 1 (2003), pp. 167-174.

Sztaba M., Człowiek jako byt moralny w myśli Karola Wojtyły - Jana Pawła II, in: Człowiek $w$ refleksji Karola Wojtyły - Jana Pawła II. Wybrane aspekty adekwatnej antropologii, ed. A. Różyło, M. Sztaba, Lublin 2014, pp. 115-137.

Tischner J., Metodologiczna strona dzieła „Osoba i czyn”, „Analecta Cracoviensia” 5-6 (1973-1974), pp. 85-89.

Wojtyła K., Człowiek jest osobq, in: „Osoba i czyn” oraz inne studia antropologiczne, ed. T. Styczeń, W. Chudy, J. W. Gałkowski, A. Rodziński, A. Szostek, Lublin 2000, pp. 415-420.

Wojtyła K., Człowiek w polu odpowiedzialności, Rzym-Lublin 1991.

Wojtyła K., Dobro i wartość, in: Wykłady lubelskie, ed. T. Styczeń, W. Chudy, J. W. Gałkowski, A. Rodziński, A. Szostek, Lublin 2006, pp. 75-178.

Wojtyła K., Love and Responsibility, trans. H. T. Willetts, San Francisco 1981.

Wojtyła K., Ocena możliwości zbudowania etyki chrześcijańskiej przy założeniach systemu Maxa Schelera, in: Zagadnienie podmiotu moralności, ed. T. Styczeń SDS, J. W. Gałkowski, A. Rodziński, A. Szostek, Lublin 2001, pp. 11-128.

Wojtyła K., Osoba i czyn, in: „Osoba i czyn” oraz inne studia antropologiczne, ed. T. Styczeń, W. Chudy, J. W. Gałkowski, A. Rodziński, A. Szostek, Lublin 2000, pp. 43-338.

Wojtyła K., Osoba: podmiot $i$ wspólnota, in: „Osoba $i$ czyn” oraz inne studia antropologiczne, ed. T. Styczeń, W. Chudy, J. W. Gałkowski, A. Rodziński, A. Szostek, Lublin 2000, pp. 317-414.

Wojtyła K., Osobowa struktura samostanowienia, in: „Osoba i czyn” oraz inne studia antropologiczne, ed. T. Styczeń, W. Chudy, J. W. Gałkowski, A. Rodziński, A. Szostek, Lublin 2000, pp. 421-432. 
Wojtyła K., Podmiotowość i „to, co nieredukowalne” w człowieku, in: „Osoba i czyn” oraz inne studia antropologiczne, ed. T. Styczeń, W. Chudy, J. W. Gałkowski, A. Rodziński, A. Szostek, Lublin 2000, pp. 433-444.

Wojtyła K., Wypowiedź wstępna w czasie dyskusji nad „Osoba i czynem” w Katolickim Uniwersytecie Lubelskim dnia 16 grudnia 1970 r., "Analecta Cracoviensia" 5-6 (19731974), pp. 53-55.

Wojtyła K., The Acting Person, trans. Andrzej Potocki, Dordrecht: Holland 1979. 